\title{
Organizational Factors and Innovativeness of Housing Developers
}

\author{
${ }^{1}$ Ahmed Mohammed Kamaruddeen, ${ }^{2}$ Nor' Aini Yusof, \\ ${ }^{2}$ Ilias Said and ${ }^{2}$ Abd Hamid Kadir Pakir \\ ${ }^{1}$ Department of Technology and Operation Management, \\ Universiti Utara Malaysia, 06010 Sintok, Kedah Darul Aman, Malaysia \\ ${ }^{2}$ Department of Construction Management, School of Housing Building and Planning, \\ Universiti Sains Malaysia, 11800 Penang, Malaysia
}

Received 2012-01-05, Revised 2012-11-11; Accepted 2012-12-10

\begin{abstract}
In examining the influence of a firm's structure and culture on innovativeness among housing developers in Malaysia, we draw a theoretical perspective to develop hypotheses, that propose the structure and culture of the firm as organizational factors which influence innovativeness. We, therefore, examine the direct relationship between independent variables (firm structure and culture) and the dependent variable (firm innovativeness). While previous empirical studies discover that certain organizational factors such as structure, size and culture influence innovativeness, the findings are however proven to be inconsistent. We used the proportionate stratified random sampling to collect data from the micro, small, large and publiclisted housing developers in Peninsular Malaysia. We received 183 valid questionnaires out of 504 questionnaires distributed, yielding $36.3 \%$ response rate. All the two dimensions of the culture examined in this study (adhocracy culture and market orientation) are found to have a positive relationship and strong influence on the firm's innovativeness. Although the relationship between firm structure and innovativeness is positive, formalization and centralization have no strong influence on innovativeness among housing developers in Malaysia. The findings from this study suggest that to enhance the innovativeness in the Malaysian housing industry, managers and chief executives need to consider cultural dimensions such as adhocracy culture and market orientations seriously. It is hoped that our findings complement the existing body of knowledge and contribute to future studies which concern innovativeness.
\end{abstract}

Keywords: Organizational Factors, Firm Structure, Firm Culture, Firm Innovativeness, Housing Developers

\section{INTRODUCTION}

The basic assumption held by innovation variance scholars is that certain organizational factors influence the firm innovativeness. For example, organizational structure and culture are found to be the success factors for small and medium-sized Enterprises (Tan, 2011). In the same line of reasoning, Tornatzky et al. (1990) have earlier categorized the factors as internal, external and technological. Moreover, previous researches suggest that several characteristics will influence the innovativeness of a firm (Katz and Allen, 2004). There is however inconsistency in some of these results (Jantan et al., 2003). For example, while previous studies have shown that organizational culture influences innovativeness (Hurley and Hult, 1998), recently, Yusof and Abidin (2011) find that culture does not significantly influence the innovativeness among Malaysian public-listed housing developers. Similarly, Brandyberry (2003) empirically examines the influence

Corresponding Author: Ahmed Mohammed Kamaruddeen, Department of Technology and Operation Management, Universiti Utara Malaysia, 06010 Sintok, Kedah Darul Aman, Malaysia 
of five firm characteristics on the adoption of architectural software (CAD). The findings reveal that the firm size does not influence the adoption of innovation. Furthermore, Rogers (1995) identifies the complexity, interconnectedness, size and firm slack to be positively related to the level of innovativeness in a firm, while centralization and formalization are negatively related to innovativeness. In other words, low level of centralization and formalization will improve the firm's innovative capability.

While many researchers have examined the influence of the firm's internal factors such as structure and culture on firm innovativeness in other industries (Katz and Allen, 2004; Hult et al., 2004), the factors that influence innovativeness among the housing developers in Malaysia have not been given considerable attention. This study, perhaps, is very much relevant to the Malaysian housing industry, considering the importance that has been placed on innovation in the 10th Malaysia Plan. Additionally, improving their innovativeness in the housing industry will require better understanding of the antecedents and consequences of the internal and external factors such as firm structure and market competition, respectively. Most researches who examine innovativeness of housing developers in Malaysia have not focused on the factors that influence this quality.

Recently, (Yusof and Shafiei, 2011) examine the factors affecting Housing Developers' readiness to adopt innovative housing delivery system in Malaysia. We note that their study fail to focus on the firm's internal factors associated with innovativeness in previous studies. In addition, the authors conceptualize innovativeness from a uni-dimensional perspective (process innovativeness) which they operationalize as the propensity to adopt the Build-Then-Sell (BTS) method of the housing delivery system. In contrast, we conceptualize the firm's innovativeness from a multi-dimensional approach as presented in the latter part of this study. Hilmi et al., (2010) examine the influence of the product, process innovativeness on the performance of Malaysian SMEs and have found out that although Malaysian SMEs are highly innovative in their products and processes, only process innovativeness shows to be an important determinant of their performance. In addition, Jantan et al. (2003) examine the influence of structure and culture among electronic/electrical, textile and telecommunication organizations operating in Malaysia. Their findings suggest that structure has no influence on the overall innovativeness of the organizations. Drawing upon the literature which sheds light on the differences of characteristics in the industry, we contend that findings relating to innovativeness in other industries cannot be generalized or extended to the housing industry (Reichstein et al., 2008). For example, while manufactured products are produced in the factories and then supplied to the consumers, housing products takes longer time to produce and are fixed, even if few manufactured and assembled components are used (Nam and Tatum, 1988). Furthermore, the housing industry constitutes a larger number of small and medium-sized firms and is dominated by a price-based competition (Gann, 2003). We note that this study differs from Yusof and Abidin (2011) in two major aspects: Firstly, our sample covers all the housing developers registered with the Real Estate and Housing Developers (REHDA) in Malaysia, inclusive of the public-listed housing developers registered with Bursa Malaysia. Secondly, while organizational culture is conceptualized in the earlier study as power distance, uncertainty avoidance, individualism-collectivism and masculinity-femininity; we have come to conceptualize culture as adhocracy culture and market orientation.

To address this research gap, we examine the influence of the firm structure and culture on innovativeness on a sample of housing developers in Malaysia. The findings can help the management and other stakeholders in the Malaysian housing industry to create a better understanding of the type of the structure and culture that should be encouraged in order to enhance innovativeness in the firm and further, to ensure better performance of the industry.

This study is organized as follows. We review the empirical and theoretical backgrounds on firm structure and culture as factors that influence innovativeness among housing developers and move on to develop the research hypotheses. In the methodology, we discuss the sample of 183 housing developers' firms operating in Malaysia; thereafter, we present the results and findings of the relationships among the constructs and finally discuss the implications of the study in the hope of contributing towards the formulation of sound theoretical policy and for future research.

\subsection{Theoretical Framework and Hypotheses}

The criterion as the variable for this study is the firms' innovativeness. The predictor variables are the firm structural and cultural characteristics. The following sections will provide the discussion of all variables contained in this study. 


\subsection{Firm Structure and Firm Innovativeness}

According to Zheng et al. (2010), the organizational structure of a firm is an indicator of an enduring configuration of tasks and activities in that firm. Organizational structure has been viewed in the literature in various perspectives. For example, it has been described as the formal system of task and reporting relationships that provide the coordination and motivation to enable employees to achieve expected outcomes (George and Jones, 1999). In sum, the organizational structure of a firm refers to things that represent the totality of links and relationships between and within its factors at all levels of the organization in precisely defined quantities (Sehanovic and Zugaj, 1997). The structural dimensions include the extent of the formalization, centralization and specialization. However, the common structural dimensions examined by scholars are formalization and centralization (Jaworski and Kholi, 1993; Jantan et al., 2003; Kirca et al., 2005; Meirovich et al., 2007; Katsikea et al., 2011). Additionally, Zheng et al. (2010) note that centralization is one prominent dimension of the structural elements of firms. In this study, we therefore examine only formalization and centralization as the structural dimensions of the firms among housing developers in Malaysia. For the purpose of definition, specialization indicates the extent of dividing organizational tasks into subtasks, whereby staff members are allocated to execute only one of these tasks (Willem et al., 2007).

\subsection{Formalization}

According to Jaworski and Kohli (1993) formalization refers to the extent to which rules and sanctions or the penalty, roles, authority relations, line of communications, norms and procedure are defined within an organization. In essence, it can be viewed as a means of maintaining the standards and rules that guide employees in achieving the goal of the firm (Auh and Menguc, 2007). On evaluating the impact of formalization in firms, Hartline et al. (2000) opine that formalization brings about the state where employees tend to become rigid and have the inclination to conform to work rules which, of course, hinder their creativity. However, in production-oriented firms formalization brings about standard and routine procedures that guide employees and avoids the duplication of similar activities. It also helps to control and provide guidelines in solving organizational problems (Auh and Menguc, 2007). Following Daugherty et al. (1992) and PertusaOrtega et al. (2010), we define formalization in this study as the degree to which decisions and working relationships are governed by formal rules and standard policies and procedures in housing development firms. In the context of the housing industry, housing developers with a formal structure will require the establishment of specific rules and procedures that indicate what needs to be done by the staff members (Katsikea et al., 2011). This type of firm's setup prevents staff members in the housing development firms from performing different activities, or rather multiple activities in the course of performing their daily jobs (Banai and Reisel, 2007).

\subsection{Centralization}

Jaworski and Kohli (1993) refer to centralization as the inverse of the amount of delegating the authority of decision-making, as well as the extent to which organizational members participate in the decisionmaking. This definition is perhaps, a multidimensional construct because it encompasses both authority and participation (Auh and Menguc, 2007). Looking from the perspective of large firms with subsidiaries and branches, centralization is the structural element that explains how decision-making authority is shared between the headquarters and the branches. It also refers to how branches or subsidiaries provide specialized services of product and serve as specific centres (Quester and Conduit, 1996). This concept is consistent with John and Martin (1984) who define centralization as "the extent to which marketing planning-related activities and decisions are concentrated within a few positions". Following Daugherty et al. (1992) and Pertusa-Ortega et al. (2010), we define centralization in the context of the housing industry as the locus of the decision-making authority and control within an entity of housing development firms. Centralization is referred to as "the extent to which decision-making power is concentrated on the top management level in the organization" and a firm is said to practise a centralized structure when the concentration of decision-making task lies on few hands in the firm (Willem et al., 2007). The general purpose of this centralized structure in a firm is to produce a uniform policy and action, minimize the tendency of committing error by staff members due to the lack of information or skills; and enable them to utilize the skills of central and specialized experts and to have a closer control of organizational operations (Katsikea et al., 2011). In the context of the housing industry, housing developers who practise a centralized structure limit the authority of the managers, in terms of the decisionmaking and sole decision power lies in the hands of the 
chief executives or directors. Consequently, centralization prevents the staff members or even managers to be flexible or to take the initiative in the course of performing their duties (Katsikea et al., 2011). Previous researches have shown that simple and less intricate organizational structure facilitates innovativeness. This is due to the flexibility and openness of this type of structure, whereby new ideas are encouraged from members of the organization (Tan, 2011). Conversely, the centralization of power is found to be a major barrier to the adoption of innovation in a highly centralized organization. Organizational innovation studies has shown that decentralization encourages internal communication among the organisational staff, improves creativity and adoption of innovation (Zheng et al., 2010). Similarly, Cohn and Turyn (1980) suggest that formalization and centralization will deter the adoption of innovation. The authors hypothesise that low levels of formalization will facilitate this kind of adoption. Formalization is the extent to which the decision-making power is concentrated at the top of the organizational hierarchy. Centralization refers to the decision-making and instruction processes concerning an operating department within an organization, whereas formalization refers to written job descriptions, policies and procedures that guide the actions of employees in an organization (Daugherty et al., 2011).

\subsection{Firm Culture and Firm Innovativeness}

According to Schein (2010), firm culture refers to a pattern of shared basic assumptions that the group learns, as it solves its problems of external adaptation and internal integration that have worked well enough to be considered valid. Therefore, such an avenue has to be taught to new members as the correct way to perceive, think and feel in relation to those problems. Understanding the culture of an organization will enable a researcher to have a glimpse at how the organization operates (Schein, 2010). Within the context of a firm or organization, culture refers to the deeply rooted values and beliefs shared by employees at all levels, manifested in the characteristics of the organization (Claver et al., 1998). The relationship between the culture of a firm and its innovativeness is well documented in the literature (Hurley and Hult, 1998). Value and belief in firms have been found to have an influence on innovation (Tesluk et al., 1997; Harris, 2011). This is also consistent with Schein (2010) and Weick (1985), who both describe culture as an important element that stimulates innovation in firms. Following Cameron and
Quinn (2011) and Jaworski and Kohli (1993), we have conceptualized firm culture as adhocracy culture and market orientation.

\subsection{Adhocracy Culture}

Firms embedded with adhocracy culture are characterized as dynamic, entrepreneurial and creative places to study, where people are ready to take risks. The leaders in such firms are normally characterized as innovators and risk takers. The common practice among members of these firms is commitment to experimentation and innovation; the main goal is to be on the leading edge. The firm's long-term goal is to grow and acquire new resources. Success refers to gaining uniqueness, new products, or services and being a product or service leader. The firm encourages individual initiatives and allows freedom to experiment new things (Cameron and Quinn, 2011).

The clan culture focuses on the internal organization and is associated with flexibility and change. Adhocracy focuses on the external organizational growth and is characterized with flexibility, resources' acquisition, creativity as well as adaptation. Hierarchical culture is associated with focus given on firm productivity, achievement and tends to respond to external competition. Market culture is characterized as a concept focusing on the internal stability, internal efficiency, compliance to rules and regulations of the firm (Shih and Huang, 2010). Following Byrd and Marshall (1996), we examine only adhocracy based on the four types of the firm's culture. A firm that is embedded with adhocracy culture is also called the open system organization. It is also one of the two types prevalent among culture studies. Additionally, adhocracy culture represents one of the two opposites and extreme views of firm culture (Byrd and Marshall, 1996). Adhocracy culture enhances the expansion, transformation of the firm and focuses on the competitiveness and insight of the firm. The members in this cultured firm are driven and motivated by growth as well as creativity. The leaders in this type of firms continuously attempt to seek for additional resources, capture external support and are willing to take risks. Flexibility is what underlies the existence of the firm and focuses on the external environment (Danison and Spreitzer, 1991). In summary, a firm embedded with adhocracy culture is expected to have a climate of entrepreneurship and creativity whereby the firm's strategic emphases is on innovation, growth and the acquisition of new resources (Hynes, 2009). 


\subsection{Market Orientation}

According to Korhonen-Sande (2010), definitions of market orientation that have received considerable acceptance within this field of research are those from Slater and Naver (1990); Kohli and Jaworski (1990) and Jaworski and Kohli (1993). These scholars have identified two perspectives of market orientation: Cultural and behavioural. In particular, the operationalization of the market orientation concept by Kohli and Jaworski (1990) has received much acceptance among scholars (Gonzalez-Benito and Gonzalez-Benito, 2005). While Slater and Naver (1990) concept of market orientation relates to norms and values that are instilled in the market-oriented behaviour in a firm, Kohli and Jaworski (1990) focuses on core activities of the firm, such as acquiring market information, disseminating information within departments or units and using the information strategically to respond to the changing market condition. In this vein, Santos-Vijande et al. (2005) observe that market orientation can be viewed from two levels: Firstly as a culture that enables a firm to offer greater value to customers; secondly, as a set of firm's actions that relates to implementing marketing concepts. According to Slater and Narver (1994), market orientation is considered as an organizational culture because it involves the adoption of marketing concepts as a firm's business philosophy. Market-oriented firms give much attention and priority to customers and are interested to attain long-term profitable firms (GonzalezBenito and Gonzalez-Benito, 2005). This group of firms believe that satisfying the customers is the most effective way to achieve a position to achieve their objectives (Shoham and Rose, 2001). In examining the definitions of market orientation in the literature, Chen and Quester (2009) have identified three major components of market orientation: Customer focus, process emphasis and goal achievement. The aim of the firms in performing these three components is to satisfy customers' needs and wants, thereby achieving their business goals. Hence, market-oriented firms are distinguished when they possess the ability to generate, disseminate and use superior information relating to their customers and competitors (Jimenez-Jimenez and Sanz-Valle, 2011). Following Narver and Slater (1990) concept of market orientation, Chen and Quester (2009) define market orientation as "the organization culture that most effectively and efficiently creates the necessary behaviours for the creation of superior value for buyers and, thus generates continuous superior performance for business".
In this study, we adapt the definition of market orientation provided by Narver et al. (1998) to suit the housing development firms. We define market orientation as the culture in which all housing developers' employees are committed, towards achieving continuous creation of superior value for the firms' customers. A shared vision-led senior management participatory role has been identified as critical to the successful implementation of the market-oriented culture in firms such as those owned by the housing developers. Market orientation efforts will perhaps influence employees to adopt new assumptions as part of their daily work behaviours. In addition, implementing market orientation will require the top management to affect changes by abolishing past practices relating to the firm's status quo; and change the balance existing between driving and resistance forces in favour of the intended change (Beverland and Lindgreen, 2007; Kennedy et al., 2003). According to Kohli and Jaworski (1990), market orientation refers to behaviour and activities associated with the generation and dissemination, as well as the responsiveness to market intelligence. This is consistent with Day (1994), where the scholar views market orientation as the behaviour and process in an organization that is ongoing, in relation to market and customers. His concept of market orientation is that market-oriented organizations will always devise ways of obtaining market intelligence into their strategic decision-making process. Therefore, Day suggests that market intelligence should be collected from outside the organization. Hult et al. (2004) describe market orientation as a latent construct and an aspect of organizational culture that can be measured in terms of value, belief and concern for the market. It means that market-oriented firms or organizations will always pay utmost attention to all that happen in the market, particularly to the customers. In addition, Hult et al. (2004) have associated market-oriented firms or organizations with innovativeness. The reason being that innovativeness is very likely to flow in the firms out of the special attention given to market situations, which eventually lead to innovative behaviours. We therefore infer that market orientation does have a link with innovativeness. This is consistent with earlier studies (Deshpande and Farley, 2004; Henard and Szymanski, 2001). As Rhee et al. (2010) have noted, previous research has conceptualized market orientation as either organizational behaviour or culture. For example, while Jaworski and Kohli (1993) concept is behaviour-related, Narver and Slater (1990) is culture-related. 


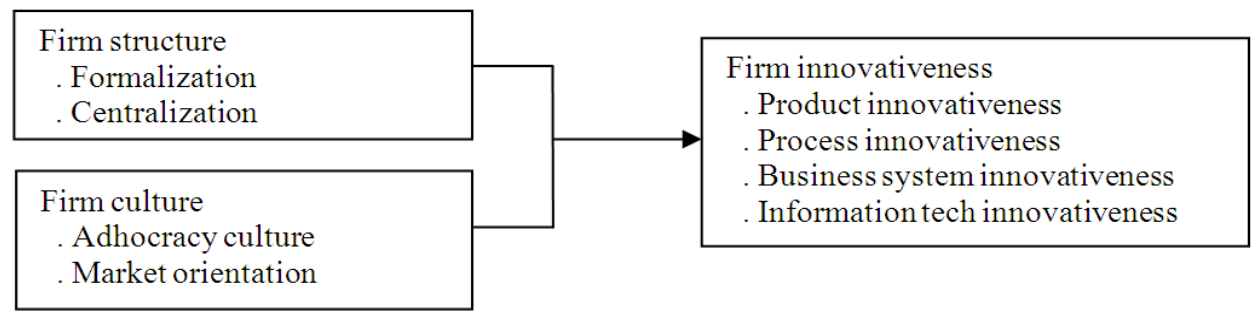

Fig. 1. Theoretical framework

As Kohli and Jawoski (1990) have suggested, the behavioural concept of market orientation consists of three activities: The generation of market intelligence, the dissemination of the intelligence across the organization's departments and responsiveness to information. According to Narver and Slater (1990), market orientation consists of customer-orientation, competitor-orientation and inter-functional coordination.

\subsection{The Firm's Innovativeness}

Following Kamaruddeen et al. (2009; 2011), we define firm innovativeness in the context of the housing industry as the capacity or the propensity of a firm to adopt innovative building products, construction methods/processes/concepts, business systems and information technology that is new to the firm and/or the housing industry, not just for profit-making but towards meeting the need of the customers or end-users' sustainability and environment-consciousness. Meanwhile, Innovative capacity refers to the continuous improvement of capabilities and resources that a firm possesses to exploit the opportunity for getting large share of the market (Szeto, 2000). Carayannis and Provance (2008) define 'propensity' as the "firm's ability to capitalize on its posture based on cultural acceptance of innovation". We adapt Knowles et al. (2008) conceptualization of the firm's innovativeness to suit the housing industry as the product, process, business system. Business system could be the opening or development of the new market, marketing methods, introduction of a new management system, while 'process' could include the manufacturing process and new administrative process towards innovativeness. Based on Wang and Ahmed (2004) we consider information technology as a dimension of firm innovativeness. We therefore add the information technology to product, process, business system's innovativeness, which total four dimensions of innovativeness. The direct relationships between the variables are depicted in Fig. 1.
We therefore hypothesize that:

- H 1: There is a significant relationship between the firm's structure and innovativeness among housing developers in Malaysia

- H 1(A): There is a significant relationship between formalization and innovativeness among housing developers in Malaysia

- $\quad$ H 1(B): There is a significant relationship between centralization and innovativeness among housing developers in Malaysia

- H 2: There is a significant relationship between the firm's culture and innovativeness among housing developers in Malaysia

- $\quad$ H 2(A): There is a significant relationship between adhocracy culture and innovativeness among housing developers in Malaysia

- $\quad$ H 2(B): There is a significant relationship between market orientation and innovativeness among housing developers in Malaysia

\section{MATERIALS AND METHODS}

\subsection{Sample and Data Collection}

We obtained the sample frame of 987 housing developers from the fifth edition of the Real Estate and Housing Developers' Association (REHDA) Directory published in 2010. This sample is inclusive of the publiclisted companies drawn from our local newspaper, The Star on Saturday 10 April, 2010. At the time of this research, there was no single, comprehensive and updated list that classified housing developers according to size and ownership status. The managers were the respondents, where they had to assess all the constructs that had constituted our proposed model. Following the completion of the pre-test study with two academics and 35 housing developers to assess the research instrument, we mailed 504 questionnaires to managers along with pre-addressed postage-paid envelops and a cover letter 
for each recipient, explaining the purpose of the research and confidentiality of their responses. A total of 183 completed, usable questionnaires were returned which yielded 36.3\% response rates. The Cronbach's coefficient alpha was used to determine the reliability of the various items used in the study. All the Cronbach's coefficient alpha values obtained in this study are above 0.7- the minimum acceptable values (Nunnally and Bernstein, 2010).

\subsection{Measurement of Variables}

Firm structure was measured by a twelve-item instrument adopted from Jaworski and Kholi (1993) and was conceptualized as the formalization and centralization. While formalization refers to written job descriptions, also policies and procedures that guide the actions of employees in an organization, specialization refers to the willingness and ability to transfer employees among different departments within an organization and centralization refers to the centrality of location of decision-making. Elsewhere, specialization refers to specialized skills of personnel in the entire functional areas firm (Chiu and Chang, 2009). Respondents were asked to indicate the intensity of formalization and centralization in their firms on a five-point Likert scale ranging from (1) "not at all" to (5) ". Firm culture was measured using the tool proposed by Cameron and Quinn (2011) named the "Organizational Culture Assessment Instrument" (OCAI). The aim is to assess the extent of adhocracy culture practice among housing developers in Malaysia. We, therefore, adopt only the items for adhocracy culture. Following Cameron and Quinn (2011); Duygulu and Ozeren (2009) and Hurley and Hult (1998), firm culture is conceptualized as adhocracy culture and market orientation. Respondents were asked to indicate the extent of adhocracy culture and market orientation in their firms on a five-point Likert-scale ranging from (1) "not at all" to (5) ". Based on the existing innovativeness literature, we have added information technology's innovativeness dimension to the product, process and business system's innovativeness. Firm product, process and business system's innovativeness were measured using the eleven-item instrument adapted from Knowles et al. (2008) and six were adapted from Beatty et al. (2001) to measure information technology's dimension of innovativeness. Respondents were asked to indicate the intensity of adopting or introducing new product, process, business and information technology to their firms on a five-point Likert Scale ranging from (1) "not at all" to (5) "completely true".

\section{RESULTS AND DISCUSSION}

\subsection{Data Analyses}

Following (Sonmez and Sirakaya, 2002), a factor analysis was performed separately for each construct: Firm structure, firm culture, firm resources, firm external factors and firm innovativeness. Additionally, a reliability test was performed on all the constructs to determine the data reliability.

\subsection{Firm Structure}

The twelve items measuring firm structure were submitted to the principle behind the component analysis with the varimax rotation. All items had a Measure of the Sampling Adequacy (MSA) that was greater than 0.5 (Hair et al., 2009). Additionally, the Kaiser-Meyer-Olkin measure of sampling adequacy was 0.849 and Bartlett's Test of Sphericity is significant with a value of 0.000 . Based on the rotated component matrix, four (4) items were dropped due to the high cross loading. Two factors met the selection criteria of Eigen values greater than 1.0 , explaining $71.45 \%$ of the variance. All individual loadings were above the minimum of 0.5 (Hair et al., 2009). The reliability test performed after the factor analysis for items measuring firm structure is $0.869(\alpha=$ 0.869). Based on the Alpha value obtained, the internal consistency reliability of the measures for firm structure was acceptable as shown in Table 1.

\subsection{Firm Culture}

The twenty-one (21) items measuring firm culture were submitted to the main component analysis with the varimax rotation. As Hair et al. (2009) recommend, all items have a Measure of Sampling Adequacy (MSA) greater than 0.5. Additionally, the Kaiser-Meyer-Olkin measure of sampling adequacy was 0.918 and Bartlett's Test of Sphericity was significant with a value of 0.000 .

Based on the rotated component matrix, eight (8) items were dropped due to high cross loading. Two factors met the selection criteria of Eigen values greater than 1.0, explaining $71.187 \%$ of the variance. All individual loadings were above the minimum of 0.5 (Hair et al., 2009). The reliability test performed after the factor analysis for items measuring firm structure was $0.946(\alpha$ $=0.946$ ). Based on the Alpha value obtained, the internal consistency reliability of the measures for firm structure was acceptable. The results of factor analysis tests are presented in Table 2. 
Table 1. Firm structure: Rotated factors, item loading and reliability

\begin{tabular}{|c|c|c|c|c|c|c|}
\hline Factors & & loading & Communality & Eigen value & Variance & Mean \\
\hline Formalization & & & & 4.21 & 42.41 & 2.06 \\
\hline Employee's freedom & & 0.849 & 0.800 & & & \\
\hline Employee make rules & & 0.847 & 0.740 & & & \\
\hline Employees' discretion & & 0.818 & 0.687 & & & \\
\hline Centralization & & & & 1.51 & 29.04 & 2.92 \\
\hline Supervisor's approval & & 0.738 & 0.649 & & & \\
\hline Management endorsement & & 0.862 & 0.753 & & & \\
\hline Permission from boss & & 0.843 & 0.747 & & & \\
\hline Approval from boss & & 0.814 & 0.678 & & & \\
\hline Discourage own decision & & 0.782 & 0.662 & & & \\
\hline Total Variance Explained & 71.45 & & & & & \\
\hline Total Scale Reliability & 0.869 & & & & & \\
\hline KMO & 0.849 & & & & & \\
\hline Bartlett's Test of sphericity & 0.000 & & & & & \\
\hline
\end{tabular}

Table 2. Firm culture: Rotated factors, item loading and reliability

\begin{tabular}{|c|c|c|c|c|c|c|}
\hline Factors & & Loading & Communality & Eigen value & Variance & Mean \\
\hline Adhocracy culture & & & & 1.59 & 433.16 & 3.44 \\
\hline Dynamic place & & 0.570 & 0.71 & & & \\
\hline Entrepreneurial place & & 0.794 & 0.72 & & & \\
\hline Exemplifies risk taking & & 0.796 & 0.66 & & & \\
\hline Freedom practice & & 0.711 & 0.52 & & & \\
\hline Unique management style & & 0.770 & 0.69 & & & \\
\hline Innovation commitment & & 0.550 & 0.74 & & & \\
\hline Basis of firm success & & 0.560 & 0.59 & & & \\
\hline Market Orientation & & & & 7.67 & 38.03 & 3.923 \\
\hline Response to competition & & 0.610 & 0.66 & & & \\
\hline Attention to after sales & & 0.810 & 0.72 & & & \\
\hline Customer satisfaction & & 0.760 & 0.72 & & & \\
\hline Competitive advantage & & 0.860 & 0.83 & & & \\
\hline Customer needs & & 0.930 & 0.89 & & & \\
\hline Customer value & & 0.880 & 0.82 & & & \\
\hline Total variance explained & 71.187 & & & & & \\
\hline Total scale reliability & 0.946 & & & & & \\
\hline $\mathrm{KMO}$ & 0.918 & & & & & \\
\hline Bartlett's test of sphericity & 0.000 & & & & & \\
\hline
\end{tabular}

\subsection{Firm Innovativeness}

The seventeen (17) items measuring firm innovativeness were submitted to principle component analysis with the varimax rotation. All items had a Measure of Sampling Adequacy (MSA) that was greater than 0.5 (Hair et al., 2009). Additionally, the KaiserMeyer-Olkin's measure of sampling adequacy was 0.933 and Bartlett's Test of Sphericity was found significant with a value of 0.000 . Based on the rotated component matrix, two (2) items were dropped due to high cross loading. Three factors met the selection criteria of Eigen values greater than 1.0 , explaining $73.996 \%$ of the variance. All individual loadings were above the minimum of 0.5 (Hair et al., 2009). The reliability test performed after the factor analysis for items measuring firm structure was conducted, read $0.95(\alpha=0.95)$. Based on the Alpha value obtained, the internal consistency reliability of the measures for firm structure had been acceptable. The results of the factor analysis tests are presented in Table 3. The items in the constructs were subjected to a data purification process involving a series of exploratory factor analyses. To examine the relationships between the variables and the testing of the hypotheses developed in this study, we have conducted correlation and regression analyses.

Table 4 presents the demographic statistics of the respondents and firms. Out of 183 respondents who participated in the survey, $9.8 \%$ are executive directors; $1.6 \%$ senior executives; $70.3 \%$ managers and $18.0 \%$ other senior employees. 
Table 3. Firm innovativeness: Rotated factors, item loading and reliability

\begin{tabular}{llllll}
\hline Factors & Qsn & Factor & Communality & Eigen value & Variance \\
\hline Product/Process/Business & & & & 9.04 & 46.96 \\
Innovation & $(1)$ & 0.85 & 0.75 & & \\
Adopt products early & $(2)$ & 0.81 & 0.78 & \\
Used by other firms & $(3)$ & 0.76 & 0.71 & \\
Seek innovative products & $(4)$ & 0.89 & 0.84 & \\
Adopt process early & $(5)$ & 0.85 & 0.79 & \\
Used by other firms & $(6)$ & 0.80 & 0.67 & \\
In-house solution & $(7)$ & 0.83 & 0.66 & \\
Seek innovative process & $(8)$ & 0.77 & 0.66 & \\
Create new business system & $(9)$ & 0.86 & 0.82 & \\
Adopt new business early & $(11)$ & 0.75 & 0.66 & \\
Business outside the firm & & & & \\
Information technology & $(12)$ & 0.76 & 0.60 & \\
Computer literate & $(13)$ & 0.81 & 0.75 & \\
Encourage the use of infotech & $(14)$ & 0.84 & 0.78 & \\
Well-computerized firm & $(15)$ & 0.84 & 0.75 & \\
High connectivity & $(16)$ & 0.82 & 0.76 & \\
Online transactions & 73.99 & & & \\
Total variance explained & 0.952 & & & \\
Total Scale Reliability & 0.933 & & & \\
KMO & 0.000 & & & \\
Bartlett's Test of sphericity & & &
\end{tabular}

Qsn: Serial number of items in the questionnaire

Table 4. Demographic breakdown of respondents

\begin{tabular}{|c|c|c|}
\hline Variable & Frequency & Percentage \\
\hline \multicolumn{3}{|l|}{ Position in firm } \\
\hline Manager & 118 & 64.20 \\
\hline Executive director & 18 & 9.80 \\
\hline Engineer/QS/Land surveyor & 11 & 6.00 \\
\hline Senior executive & 3 & 1.60 \\
\hline Other senior employee & 33 & 19.60 \\
\hline \multicolumn{3}{|l|}{ Working experience } \\
\hline $1-5$ years & 62 & 43.20 \\
\hline $6-10$ years & 46 & 27.60 \\
\hline $11-15$ years & 26 & 15.60 \\
\hline $16-20$ years & 16 & 9.60 \\
\hline $21-25$ years & 3 & 1.80 \\
\hline 26-30 years & 2 & 1.20 \\
\hline 31-36 years & 2 & 1.20 \\
\hline \multicolumn{3}{|l|}{ Firm Size } \\
\hline Micro & 33 & 18.00 \\
\hline Small & 77 & 42.10 \\
\hline Medium & 57 & 31.10 \\
\hline Large & 15 & 15.82 \\
\hline \multicolumn{3}{|l|}{ Firm Ownership type } \\
\hline Private limited & 127 & 69.40 \\
\hline Public limited & 17 & 9.30 \\
\hline Public listed companies & 16 & 8.70 \\
\hline Corporation & 12 & 6.60 \\
\hline Partnership & 6 & 3.30 \\
\hline Sole proprietor & 2 & 1.10 \\
\hline Others & 3 & 1.60 \\
\hline \multicolumn{3}{|l|}{ Firm business location } \\
\hline Local market (within a state) & 105 & 57.40 \\
\hline Within few states & 29 & 15.80 \\
\hline Regional & 28 & 15.30 \\
\hline Across Malaysia & 14 & 7.70 \\
\hline International market & 7 & 3.80 \\
\hline
\end{tabular}

Their working experiences range from 1-36 years; specifically, working experiences of $1-5$ years account for $43.2 \%$, those with experiences $6-10$ years account for $27.6 \%, 11-15$ years for $15.6 \%$ and $16-20$ years for $9.6 \%$.

As for gender, the percentage of male respondents was $68.9 \%$ compared to $31.1 \%$ female. The ownership of the firms ranges from public, private limited to public listed companies. The category of ownership with the largest number of companies is private limited firms at $69.4 \%$, followed by public limited firms (governmentowned companies) at $9.3 \%$, public listed firms at $8.7 \%$, incorporated companies at $6.6 \%$ and partnerships at $3.3 \%$. Following Loecher (2000), the firms were categorized into micro (1-9 employees), small (10-49 employees), medium-sized (50-249 employees) and large (above 249 employees). The highest age was marked by firms with 30 employees $(5.7 \%)$, followed by those with 25 employees $(4.4 \%)$, then firms with $50(4.1 \%)$ and 78 (3.8\%) employees respectively. The results show that micro firms accounted for 18\%, small firms $42.1 \%$, medium-sized firms $31.1 \%$ and large firms for $9.6 \%$.

\subsection{Correlation between firm Innovativeness, Structure and Culture}

Table 5 shows the correlation between firm innovativeness and firm structure. 
Table 5. Correlation between firm innovativeness and firm structure

\begin{tabular}{|c|c|c|c|c|c|c|c|}
\hline & 1 & 2 & 3 & 4 & 5 & 6 & 7 \\
\hline 1. Innovativeness & 1.000 & & & & & & \\
\hline 2. Firm structure & $0.494 * *$ & 1.000 & & & & & \\
\hline 3. Firm culture & $0.807 * *$ & $0.464 * *$ & 1.000 & & & & \\
\hline 4. Formalization & $0.302 * *$ & $0.814 * *$ & $0.307 * *$ & 1.000 & & & \\
\hline 5. Centralization & $0.515 * *$ & $0.872 * *$ & $0.464 * *$ & $0.425 * *$ & 1.000 & & \\
\hline 6. Adhocracy culture & $0.755 * *$ & $0.537 * *$ & $0.936^{* *}$ & $0.397 * *$ & $0.504 * *$ & 1.000 & \\
\hline 7. Market orientation & $0.732 * *$ & $0.294 * *$ & $0.904 * *$ & 0.144 & $0.337 * *$ & $0.696 * *$ & 1.0 \\
\hline
\end{tabular}

**. Correlation is significant at the 0.01 level (2-tailed)

Table 6. Result of multiple regression for firm structure and firm culture on firm innovativeness

\begin{tabular}{lllllllll}
\hline Variables & Beta & $\mathrm{t}$ & Sig. & Tolerance & VIF & Std. Error & Mean & SD \\
\hline Constant & 2.936 & 0.0040 & & & & 0.173 & & \\
Formalization & 0.017 & 0.348 & 0.728 & 0.724 & 1.348 & 0.044 & 2.060 & 0.926 \\
Centralization & 0.184 & 3.565 & 0.000 & 0.686 & 1.458 & 0.039 & 2.924 & 1.100 \\
Adhocracy culture & 0.371 & 5.452 & 0.000 & 0.394 & 2.539 & 0.062 & 3.442 & 0.919 \\
Market orientation & 0.409 & 6.737 & 0.000 & 0.494 & 2.023 & 0.057 & 3.937 & 0.881 \\
Innovativeness & & & & & 3.618 & 0.831 & & \\
\hline
\end{tabular}

$\mathrm{R}^{2}=67.9 \% \mathrm{~F}=93.14$ Sig. $=0.000$

It is found that Pearson ( $r$ ), for the association between innovativeness and firm structure is 0.494 and significant at $\mathrm{p}<0.01$. However, the strength of the relationship is moderate (Pallant, 2001). Table 5 also presents the Pearson correlation between innovativeness and formalization and centralization. The strength of association between formalization and innovativeness ( $r$ ) is 0.302 and significant at $p<0.01$; the $r$ for centralization and innovativeness is also positive at 0.515 and significant at $\mathrm{p}<0.01$. This result shows that innovativeness is positively associated with formalization and centralization. The result provides the statistical evidence to support $\mathrm{H} 1$ (A) and H1 (B). Table 6 shows that the Pearson correlation coefficient (r) between innovativeness and adhocracy culture is 0.755 and significant at $\mathrm{p}<0.01$; the correlation coefficient for market orientation and innovativeness is also positive at 0.732 and significant at $p<0.01$ The result therefore, provides the statistical evidence to support H2 (A) and H2 (B).

\subsection{Hypothesis Testing}

Table 6 presents the mean, standard deviations and regression parameters. The results of the multiple regression show that firm structure significantly explains firm innovativeness for $24.4 \%\left(\mathrm{R}^{2}=0.244, \mathrm{~F}=57.812\right.$, $\mathrm{p}<0.01)$. Firm structure is $(\mathrm{B}=0.478, \mathrm{t}=7.603, \mathrm{p}<0.01)$. The result also shows that firm culture can significantly explain firm innovativeness which is $65.2 \%\left(\mathrm{R}^{2}=0.652\right.$, $\mathrm{F}=335.262, \mathrm{p}<0.01)$. Firm culture is $(\mathrm{B}=0.808, \mathrm{t}$ $=18.310, \mathrm{p}<0.01)$. Although the relationship between firm structure and innovativeness is positive and moderate, the structure does not contribute significantly in explaining the sense of innovativeness among housing developers in Malaysia. Hence, structural components are not good determinants of innovativeness among our local housing developers. The perception of housing developers on the formalization is low (2.06) with the standard deviation of 0.926 . Centralization, on the other hand, has a higher mean score of 2.924 with a standard deviation of 1.10 . The perception of, market orientation (3.937) among housing developers is the highest followed by the adhocracy culture which is moderate (3.442). With regards to the firm's innovativeness, the overall mean score is 3.618 which is considered high on a 5-point scale used in the questionnaire. The overall power of the firm's structure and culture is high with $\mathrm{R}^{2}$ value of $67.9 \%$, yet, the Beta value in the regression output shows that the culture offers the strongest unique contribution in explaining the innovativeness among housing developers in this country.

From Table 6, the mean score of 2.06 for formalization demonstrates that the use of rules and procedure relating to job decision and process among Malaysian housing developers appears to be low, indicating a low degree of formalization. This implies that their employees have rather obvious restrictions on what, when and how to perform their tasks.

\section{CONCLUSION}

This study examines the relationship between the firm's structure, culture and innovativeness among 
housing developers in Malaysia. This study attempts to answer this research question: What is the influence of the firm's structure and culture on innovativeness among housing developers in Malaysia? Housing developers listed on the Real Estate and Housing Developers Association members (REHDA) including the publiclisted firms were stratified in states and were randomly and proportionately selected for the survey. A booklet containing a structured questionnaire was mailed to 504 housing developers. We subsequently followed up with a telephone call as a reminder and as an effort to improve the response rate. A total of 183 useable responses had been obtained. The data was analysed using the factor analyses, correlation and regression with the aid of the SPSS for the window-Released 17.0 software. In this study, we describe innovativeness as a measurement of attributes that reflects the extent of innovation adoption in a firm. The mean scores obtained imply that the level of formalization and centralization perceived among housing developers in Malaysia is low. Meanwhile, the adhocracy culture and market orientation are perceived to be moderate. Additionally, the overall innovativeness among housing developers in Malaysia is perceived to be high. In sum, the result obtained from this study has indicated that the firm's culture is an important determinant of innovativeness among housing developers in Malaysia. Specifically, all two dimensions of the culture examined in this study (adhocracy culture and market orientation) are found to have a positive relationship and strong influence on the firm's innovativeness. The finding associated to the positive impact of adhocracy culture is consistent with those of previous studies (Cameron and Quinn, 2011). The existence of a strong and positive relationship between the firm's culture and innovativeness is also consistent with Jantan et al. (2003) who examine the influence of culture and structure on innovativeness among manufacturing and service companies operating in Malaysia and further find out that the structural components of these firms do not have any significant impact on the organizational innovativeness. Similarly, the existence of a positive relationship between market orientation and innovativeness as discovered in the current study is consistent with previous studies (for example Jaworski and Kohli (1993). In market-oriented firms, innovativeness is very much likely to flow out of the special attention given to market situations which eventually lead to innovative behaviours. There are two possible explanations to the non-significant impact of the firm's structure on innovativeness. Firstly, the significant correlation between the structure and culture is an indication that managers who have participated in the survey may have perceived formalization and centralization as being determined by the chief executives of the firms. Hence, the company's structure is perceived to be beyond their control and is therefore subsumed by its culture. Secondly, the sample has appeared as such that the age of managers who have participated in the survey is far more than that of the chief executives, as shown in Table 4.

From practical point of view, the findings from this study suggest that to enhance the innovativeness in the Malaysian housing industry, managers and chief executives need to consider cultural dimensions such as adhocracy culture and market orientations seriously. For example, the adhocracy culture can be inculcated in the firm through continuous resource acquisition; the focus on the firm's external growth; strategic emphasis on innovation, creativity and adaptation. Similarly, market orientation can be implemented through the strategic acquisition of market information to respond to the changing market condition; by offering greater value to customers and implementing effective, practical marketing concepts. Furthermore, this study is important to the relevant stakeholders of the housing industry such as the Ministry of Housing and Local Government in Malaysia, the Real Estate and Housing Developers Association and the House Buyers Association. Additionally, our findings are thought to be able to contribute to future studies on innovativeness.

There are some reasons to explain why our findings contradict with Yusof and Abidin (2011) result. First of all, our sample was drawn from all housing developers registered with the Real Estate and Housing Developers Association; including the public-listed ones. Secondly, we introduce information technology as a dimension of firm innovativeness. This study, therefore demostrates that small sample has significantly influenced their research findings.

We have considered the use of a single respondent in capturing data at the firm level; and the use of the survey method as two major limitations emerging from this study. Having said that, future studies should consider collecting data from multiple respondents. In addition, more attention should be given to the influence of moderating variables (such as firm size and location) on the relationships between organizational factors and their innovativeness.

\section{ACKNOWLEDGEMENT}

The researchers acknowledge the Malaysian Research University (RU) Grant Scheme. 


\section{REFERENCES}

Auh, S. and B. Menguc, 2007. Performance implications of the direct and moderating effects of centralization and formalization on customer orientation. Ind. Market. Manage., 36: 1022-1034. DOI: 10.1016/j.indmarman.2006.02.010

Banai, M. and W. Reisel, 2007. The influence of supportive leadership and job characteristics on work alienation: A six-country investigation. J. World Bus., 42: 463-476. DOI: 10.1016/j.jwb.2007.06.007

Beatty, R.C., J.P. Shim and M.C. Jones, 2001. Factors influencing corporate web site adoption: A timebased assessment. Inform. Manage., 38: 337-354. DOI: 10.1016/S0378-7206(00)00064-1

Beverland, M.B. and A. Lindgreen, 2007. Implementing market orientation in industrial firms: A multiple case study. Ind. Market. Manage., 36: 430-442. DOI: 10.1016/j.indmarman.2005.12.003

Brandyberry, A.A., 2003. Determinants of adoption for organisational innovations approaching saturation. Eur. J. Innov. Manage., 6: 150-158. DOI: 10.1108/14601060310486226

Byrd, T.A. and T.E. Marshall, 1996. Corporate culture, related chief executive officer traits and the development of executive information systems. Comput. Hum. Behav., 12: 449-464. DOI: 10.1016/0747-5632(96)00018-0

Cameron, K.S. and R.E. Quinn, 2011. Diagnosing and Changing Organizational Culture: Based on the Competing Values Framework. 3rd Edn., John Wiley and Sons, New York, ISBN-10: 1118003322 , pp: 272.

Carayannis, E.G. and M. Provance, 2008. Measuring firm innovativeness: towards a composite innovation index built on firm innovative posture, propensity and performance attributes. Int. J. Innov. Regional Development., $\quad 1$ : 90-107. DOI: 10.1504/IJIRD.2008.016861

Chen, S.C. and P.G. Quester, 2009. A value-based perspective of market orientation and customer service. J. Retail. Customer Service., 16: 197-206. DOI: 10.1016/j.jretconser.2008.11.015

Chiu, S.K. and K.F. Chang, 2009. Organizational structure, support mechanism and commercialization performance: A governance perspective. Int. J. Commerce Mange., 19: 183-194. DOI: $10.1108 / 10569210910987967$
Claver, E., J. Llopis, D. Garcia and H. Molina, 1998. Organizational culture for innovation and new technological behavior. J. High Technol. Manage. Res., 9: 55-68. DOI: 10.1016/1047-8310(88)900053

Cohn, S.F. and R.M. Turyn, 1980. The structure of the firm and the adoption of process innovation. IEEE Trans. Eng. Manage., 27: 98-102.

Danison, D.R. and G.M. Spreitzer, 1991. Organizational culture and organizational development: A competing values approach. Organ. Change Dev., 5: $1-21$.

Daugherty, P.J., H. Chen and B.G. Ferrin, 2011. Organizational structure and logistics service innovation. Int. J. Logistic Manage., 22: 26-51. DOI: 10.1108/09574091111127543

Daugherty, P.J., T.P. Stank and D.S. Rogers, 1992. The impact of formalization on warehousing firms. Int. J. Logistics Manage., 3: 49-62. DOI: 10.1108/09574099210804859

Day, G.S., 1994. The capabilities of market-driven organizations. J. Market., 58: 37-52. DOI: $10.2307 / 1251915$

Deshpande, R. and J.U. Farley, 2004. Organizational culture, market orientation, innovativeness and firm performance: An international research odyssey. Int. J. Res. Market., 21: 3-22. DOI: 10.1016/j.ijresmar.2003.04.002

Duygulu, E. and E. Ozeren, 2009. The effects of leadership styles and organizational culture on firm's innovativeness. Afr. J. Bus. Manage., 3: 475485.

Gann, D.M., 2003. Guest editorial: Innovation in the built environment. Constr. Manage. Econ., 21: 553555. DOI: 10.1080/0144619032000134084

George, J.M. and G.R. Jones, 1999. Understanding and Managing Organizational Behavior. 2nd Edn., Addison-Wesley, Reading, ISBN-10: 0201350637, pp: 724.

Gonzalez-Benito, O. and J. Gonzalez-Benito, 2005. Cultural vs. operational market orientation and objective vs. subjective performance: Perspective of production and operations. Ind. Market. Manage., 34:797-829.

DOI: 10.1016/j.indmarman.2005.01.002

Hair, J.F., W.C. Black and B.J. Babin, 2009. Multivariate Data Analysis: A Global Perspective. 7th Edn., Prentice Hall, Upper Saddle River, New Jersey, ISBN-10: 0135153093, pp: 800. 
Harris, J.R., 2011. The Nurture Assumption: Why Children Turn Out the Way They Do. 1st Edn., Free Press, New York, ISBN-10: 1439135088, pp: 480.

Hartline, M.D., J.G. Maxham and D.O. McKee, 2000. Corridors of influence in the dissemination of customer-oriented strategy to customer contact service employees. J. Market., 64: 35-50. DOI: 10.1509/jmkg.64.2.35.18001

Henard, D.H. and D.M. Szymanski, 2001. Why some new products are more successful than others. J. Market. Res., 38: 362-375. DOI: 10.1509/jmkr.38.3.362.18861

Hilmi, M.F., T. Ramaya, Y. Mustapha and S. Pawanchik, 2010. Product and process innovativeness: Evidence from Malaysian SMEs. Eur. J. Soc. Sci., 16: 556564.

Hult, G.T.M., R.F. Hurley and G.A. Knight, 2004. Innovativeness: Its antecedents and impact on business performance. Indus. Market. Manage., 33: 429-438. DOI: 10.1016/j.indmarman.2003.08.015

Hurley, R.F. and G.T.M. Hult, 1998. Innovation, market orientation and organizational learning: An integration and empirical examination. J. Mark., 62: 42-54. DOI: $10.2307 / 1251742$

Hynes, N., 2009. Corporate culture, strategic orientation and business performance: New approaches to modeling complex relationships. Technol. Forecast. Social Change, 76: 644-651. DOI: 10.1016/j.techfore.2008.08.014

Jantan, M., A.M. Nasurdin and N.F.A. Fadzil, 2003. Designing innovative organizations in Malaysia: Do structure and culture matter?. Global Bus. Rev., 4: 213-226. DOI: 10.1177/097215090300400201

Jaworski, B.J. and A.K. Kholi, 1993. Market orientation: Antecedents and consequences. J. Market., 57: 53-70.

Jimenez-Jimenez, D. and R. Sanz-Valle, 2011. Innovation, organizational learning and performance. J. Bus. Res., 64: 408-417. DOI: 10.1016/j.jbusres.2010.09.010

John, G. and J. Martin, 1984. Effects of organizational structure of marketing planning on credibility and utilization of plan output. J. Market. Res., 21: 170-183.

Kamaruddeen, A.M., N. Yusof and I. Said, 2011. Assessing the innovativeness of housing developers in Malaysia. Int. J. Acad. Res., 3: 178-183.

Kamaruddeen, A.M., N.A. Yusof and I. Said, 2009. A Proposed framework for measuring firm innovativeness in the housing industry. Int. J. Organ. Innov., 2: 100-129.
Katsikea, E., M. Theodosiou, N. Perdikis and J. Kehagias, 2011. The effects of organizational structure and job characteristics on export sales managers' job satisfaction and organizational commitment. J. World Bus., 46: 221-233. DOI: 10.1016/j.jwb.2010.11.003

Katz, R. and T.J. Allen, 2004. Organizational Issues in the Introduction of New Technologies. In: Psychological Dimensions of Organizational Behavior, Staw, B.M. (Ed.)., Prentice-Hall, Upper Saddle River, NJ., ISBN-10: 0130406546.

Kennedy, K.N., J.R. Goolsby and E.J. Arnould, 2003. Implementing a customer orientation: Extension of theory and application. J. Market., 67: 67-81.

Kirca, A.H., S. Jayachandran and W.O. Bearden, 2005. Market orientation: A meta-analytic review and assessment of its antecedents and impact on performance. J. Market., 69: 24-41. DOI: 10.1509/jmkg.69.2.24.60761

Knowles, C., E. Hansen and C. Dibrell, 2008. Measuring firm innovativeness: Development and refinement of a new scale. J. Forest Products Bus. Res., 5: 1-24.

Kohli, A.K. and B.J. Jaworski, 1990. Market orientation: The construct, research propositions and managerial implications. J. Market., 54: 1-18. DOI: $10.2307 / 1251866$

Korhonen-Sande, S., 2010. Micro-foundations of market orientation: Influencing non-marketing managers' customer information processing. Ind. Market. Manage., 39: 661-671. DOI: 10.1016/j.indmarman.2009.06.006

Loecher, U., 2000. Small and medium-sized enterprisesdelimitation and the European definition in the area of industrial business. Eur. Bus. Rev., 12: 261-264. DOI: 10.1108/09555340010373537

Meirovich, G., Y. Brender-llan and A. Meirovich, 2007. Quality of hospital service: The impact of formalization and decentralization. Int. J. Health Care Q. Assurance, 20: 240-252. DOI: 10.1108/09526860710743372

Nam, C.H. and C.B. Tatum, 1988. Major characteristics of constructed products and resulting limitations of construction technology. Constr. Manage. Econ., 6: 133-147. DOI: 10.1080/01446198800000012

Narver, J.C. and S.F. Slater, 1990. The effect of a market orientation on business profitability. J. Market., 54: 20-35.

Narver, J.C., S.F. Slater and B. Tietje, 1998. Creating a market orientation. J. Market-Focused Manage., 2: 241-255. DOI: 10.1023/A:1009703717144 
Nunnally, J.C. and I.H. Bernstein, 2010. Psychometric Theory. 3rd Edn., Tata McGraw-Hill Education, New Delhi, ISBN-10: 0071070885, pp: 752.

Pallant, J., 2001. SPSS Survival Manual: A Step By Step Guide to Data Analysis Using SPSS for Windows. 1st Edn., Open University Press, ISBN-10: 0335208908 , pp: 304.

Pertusa-Ortega, E.M., P. Zaragoza-Saez and E. ClaverCortes, 2010. Can formalization, complexity and centralization influence knowledge performance? J. Bus. Res., 63: 310-320. DOI: 10.1016/j.jbusres.2009.03.015

Quester, P.G. and J. Conduit, 1996. Standardisation, centralisation and marketing in multinational companies. Int. Bus. Rev., 4: 395-421. DOI: 10.1016/0969-5931(96)00020-0

Reichstein, T., A.J. Salter and D.M. Gann, 2008. Break on through: Sources and determinants of product and process innovation among UK construction firms. Indus. Innov., 15: 601-625. DOI: 10.1080/13662710802565198

Rhee, J., T. Park and D.H. Lee, 2010. Drivers of innovativeness and performance for innovative SMEs in South Korea: Mediation of learning orientation. Technovation, 30: 65-75. DOI: 10.1016/j.technovation.2009.04.008

Rogers, E.M., 1995. Diffusion of Innovations. 4th Edn., Simon and Schuster, ISBN-10: 0029266718, pp: 519.

Santos-Vijande, M.L., M.J. Sanzo-Perez, L.I. AlvarezGonzalez and R. Vazquez-Casielles, 2005. Organizational learning and market orientation: Interface and effects on performance. Ind. Market. Manage., 34: 187-202. DOI: 10.1016/j.indmarman.2004.08.004

Schein, E.H., 2010. Organizational Culture and Leadership. 4th Edn., John Wiley and Sons, ISBN10: 047064057X, pp: 464.

Sehanovic, J. and M. Zugaj, 1997. Information technologies and organizational structure. Library Manage., 18: 80-87. DOI: $10.1108 / 01435129710157699$

Shih, C.C. and S.J. Huang, 2010. Exploring the relationship between organizational culture and software process improvement deployment. Inform. Manage., 47: 271-281. DOI: 10.1016/j.im.2010.06.001

Shoham, A. and G.M. Rose, 2001. A replication, crossnational comparison and extension. J. Global Market., 14: 5-25. DOI: 10.1300/J042v14n04_02
Slater, S.F. and J.C. Narver, 1994. Does competitive environment moderate the market orientationperformance relationship? J. Market., 58: 46-55. DOI: $10.2307 / 1252250$

Sonmez, S. and E. Sirakaya, 2002. A distorted destination image? The case of Turkey. J. Travel Res., 41: 185-196. DOI: 10.1177/004728702237418

Szeto, E., 2000. Innovation capacity: Working towards a mechanism for improving innovation within an inter-organizational network. TQM Mag., 12: 149158. DOI: $10.1108 / 09544780010318415$

Tan, C.N.L., 2011. Knowledge management acceptance: Success factors amongst small and medium-size enterprises. Am. J. Econ. Bus. Admin., 3: 73-80. DOI: 10.3844/ajebasp.2011.73.80

Tesluk, P.E., J.L. Faar and S.R. Klien, 1997. Influences of organizational culture and climate on individual creativity. J. Creative Behv., 31: 21-41. DOI: 10.1002/j.2162-6057.1997.tb00779.x

Tornatzky, L.G., M. Fleischer and A.K. Chakrabarti, 1990. The Processes of Technological Innovation. 1st Edn., Lexington Books, Lexington, MA., ISBN10: 0669203483, pp: 298.

Wang, C.L. and P.K. Ahmed, 2004. The development and validation of the organizational innovativeness construct using confirmatory factor analysis. Eur. J. Innov. Manage., 7: 303-313. DOI: $10.1108 / 14601060410565056$

Weick, K.E., 1985. The Significance of Corporate Culture. In: Organizational Culture, Frost, P.J. (Ed.)., Sage Publications, Beverly Hills, CA., ISBN10: 0803924593, pp: 89-104.

Willem, A., M. Buelens and I.D. Jonghe, 2007. Impact of organizational structure on nurses' job satisfaction: A questionnaire survey. Int. J. Nurs. Stud., 44:1011-1020. DOI: 10.1016/j.ijnurstu.2006.03.013

Yusof, N. and M.W.M. Shafiei, 2011. Factors affecting housing developers' readiness to adopt innovative system. Hous. Stud., 26: 369-384. DOI: 10.1080/02673037.2011.542097

Yusof, N. and Z.N. Abidin, 2011. Does organizational culture influence the innovativeness of public-listed housing developers. Am. J. Applied Sci., 8: 724735. DOI: 10.3844/ajassp.2011.724.735

Zheng, W., B. Yang and G.N. McLean, 2010. Linking organizational culture, structure, strategy and organizational effectiveness: Mediating role of Knowledge management. J. Bus. Res., 63: 763-771. DOI: 10.1016/j.jbusres.2009.06.005 